\title{
Liquidity Determinants of Sharia and non Sharia Stocks
}

\author{
${ }^{1}$ Muhammad Madyan, ${ }^{2}$ Ubud Salim, ${ }^{3}$ Muslich Anshori, ${ }^{4}$ Solimun \\ ${ }^{1,3}$ (Economics and Business Faculty, Airlangga University, Surabaya, Indonesia) \\ ${ }^{2,4}$ (Economics and Business Faculty, Brawijaya University, Malang, Indonesia)
}

\begin{abstract}
This study was conducted to analyze and testing stock liquidity differences of sharia and non sharia stock and determinants of sharia and non sharia stock of manufacturing industry at Indonesia Stock Exchange in 2009-2010. Dependent variable of this study is stock liquidity, measured by relative spread and depth. The Independent variable are insider ownership, institutional ownership, blockholder ownership, and foreign institutional ownership, trading volume, stock price, return volatility, Market to book value, dividend policy and size. In addition, this research is also supported by qualitative data obtained from in-depth discussions with key informants, including investment managers, stock exchanges institution and stock brokers. The results showed there is no liquidity difference, both for relative spread and depth of sharia a non sharia stocks. In sharia stocks, trading volume and dividend policy has a negative effect on relative spread, whereas in non sharia stock the trading volume, stock prices and company size has a negative effect on relative spread. Institutional ownership has negative effect, while foreign institutional ownership, trading volume, dividend policy, and size has positive effect on sharia stock liquidity. For non sharia stock, the trading volume, stock prices and company size has a positive effect on depth.
\end{abstract}

Keyword: Sharia, Non Sharia, Relative Spread, Depth

\section{Introduction}

Monetary crisis in 1997 had been made Indonesian people aware the weakness of economic system that has been implemented at that time. The crisis has made many parties try to find another fairer system and structurally more resistant to moral hazard, including attempts to assess economic system based on Islamic law. Development of sharia business initially happened in banking sector and insurance then affecting on sharia capital market development. Generally, the implementation of Islamic law in capital markets, especially for stocks, is based on stocks assessment issued by each company. It is because stock instrument naturally suitable with Islamic sharia principles, namely participation in nature.

Under direction of National Sharia Board and Bapepam Rule- LK No.IX.A.13 about Sharia Stock Issuance, the main activities of an enterprise that satisfy Islamic sharia include: (a) not doing prohibited business activities, such as gambling, financial with usury concept, liquor etc. (b) not trading that is not accompanied by goods/services delivery and trade with false supply and demand, (c) does not exceed the following financial ratios: (1) Comparison of total interest-based debt with total equity not more than $82 \%$ (2) Comparison of total interest income and other forbidden income with total revenue not more than $10 \%$.

Sharia capital market development in Indonesia has shown significant progress in line with index increase, as shown in the Jakarta Islamic Index (JII). Stocks included in calculation of Jakarta Islamic Index (JII) are 30 sharia stocks, having biggest average market capitalization and high liquidity. Jakarta Islamic Index (JII) increase, although its value is not as big as the Composite Stock Price Index (CSPI) and the LQ45 index, generally the percentage JII index increase is greater than CSPI or LQ45. Table 1 shows the development of Jakarta Islamic Index (JII), Composite Stock Price Index (CSPI) and LQ45 Index

Table 1: Development of Jakarta Islamic Index (JII), Composite Stock Price Index (CSPI) and LQ45 of 2006-2010

\begin{tabular}{|c|c|c|c|c|c|}
\hline \multirow{2}{*}{ Index } & \multicolumn{5}{|c|}{ Year } \\
\cline { 2 - 6 } & $\mathbf{2 0 0 6}$ & $\mathbf{2 0 0 7}$ & $\mathbf{2 0 0 8}$ & $\mathbf{2 0 0 9}$ & $\mathbf{2 0 1 0}$ \\
\hline CSPI & 1805.52 & 2745.83 & 1,355 & 2534.36 & 3703.51 \\
\hline LQ 45 & 393.11 & 599.82 & 270 & 498.29 & 661.38 \\
\hline JII & 311.28 & 493.01 & 216.19 & 417.18 & 532.90 \\
\hline
\end{tabular}

One of sharia stock criteria is limiting percentage of debt to total assets up to $45 \%$. Therefore, financial risk for companies whose are classified as syaria stock certainly lower than company whose classified as non sharia stock. Investors have lowered their desire in trading and holding companies stocks with high debt, resulting wider bid and ask spread. However, study results of [1] states that higher leverage will increases 
company liquidity. This study results are consistent with a view that debt forcing managers to make better investment decisions [2].

Traditional market microstructure theory has categorized traders based on information system, namely; informed traders and uninformed traders [3]. Informed traders have stocks information that not owned by other traders. It creates information asymmetry between informed traders and uninformed traders related to stocks value. They exploit this information advantage when trading with other. However, in relation to information asymmetry, Islam believes that openness and transparency (full disclosure) is a condition of fair market formation, so Islam prohibits trade that containing Tadlis (manipulation and fraud) in any form. It is mandatory in order all informed parties does not make profit above normal by exploiting uninformed traders who do not have sufficient information, either about market or commodities (securities) traded. Therefore, the information asymmetry phenomena will not occur if both parties that applying Islam trade principles [4].

Liquidity is one factor for investors that will make stock exchange become passionate and running with healthy and fair. If stock market does not have liquidity capability, investors will be damaged because they will have difficulty in selling and buying the desired commodities (securities). Company stock liquidity is determined by several influencing factors. Several researchers have demonstrated several determinants of stock liquidity factors, such as institutional ownership [5,6], insider ownership [5,6,7,8], blockholder ownership $[6,7,9,10]$, foreign institutional ownership $[11,12.13]$, trade volume $[1,5,14,15]$, stock price $[5,6,10,16,17]$, return volatility [1,5,6,8,10,15], Market to book value [6.18], dividend policy [16] and company size $[1,6,15,19]$.

Institutional, insider, blockholder and foreign institutional ownership assessed as parties whose have access to company private information. They are seen as informed parties and contributing company assessment and information asymmetry level. The higher company information asymmetry level, the lower company stock liquidity $[5,6,10,13]$. Therefore, institutional, insider, blockholder and foreign institutional ownership have a negative effect on company liquidity.

Stocks that traded actively and having high transaction volume make presence level of informed traders are lower than uninformed traders [20]. Therefore, the Transactions volume has a positive effect on stock liquidity. Furthermore, a factor also considered by investors to invest stocks is stock price. Very high price has effect on investor ability to buy the stock. It affects these stocks liquidity. Adversely, very low stock price may make these stocks also not attractive and having potential not actively traded. This affect stocks liquidity. Higher market to book ratio also indicates high-growth stocks, and market to book low indicates stock with low growth. Therefore, higher market to book value will increase company growth opportunities and will also increase company liquidity. In addition, company's dividend policy also affects company liquidity. Corporate dividend policy affects equity trading behavior because investors must not sell the stocks it held to realize profits for companies that have paid dividends [16].

Last determinants of stocks liquidity is company size, the larger company, the higher company liquidity. This happens because company stock will be more frequent and easier to trade than small companies stocks. In addition, information of large company more easily available and more concerned than small companies [21]. Therefore, company size can reduce the information asymmetry, which in turn can increase company stock liquidity .

Study was conducted to analyze and testing in order to obtain empirical evidence on differences of sharia and non sharia stock liquidity and their determinant factors in manufacturing industry listed in Indonesia Stock Exchange in 2009-2010. Dependent variables used in this study is relative spread and depth as two dimensions of stocks liquidity, while its independent variables are insider ownership, institutional ownership, blockholder ownership, and foreign institutional ownership, trading volume, stock price, return volatility, Market to book value, dividend policy and size as liquidity determinant factor of sharia and non sharia stocks.

\section{Theory and Hypothesis Development}

One criterion of sharia stocks that have been mentioned, based on directive of National Sharia Board and Bapepam-LK No. IX.A.13 about Issuance of sharia Stock is limiting debt percentage to company total assets up to $45 \%$. Based on debt limitation, company's average debt of sharia stocks will be smaller than companies whose stocks are not in accordance with sharia (non sharia). Generally, company's financial risk classified as sharia stocks are also smaller than non sharia stocks.

Higher company expenses will increase financial burden and company risk that will lower company's liquidity. Companies with larger debts than equity will put stockholders at a high risk. In addition, stockholders were the last receiver of company's cash flow. Stockholders will find greater uncertainty when company's debts increased. Furthermore, high debt will lead managers (who have minimal stock) will choose a low risk project and did not take decision to maximize its value. Investors have lowered their willingness to trade and holding stocks companies with high debt. It makes stocks bid and ask spread becomes wider (not liquid) [1]. Study result [22] found a negative relationship between leverage with institutional ownership, which is negatively 
related to company stock liquidity [23]. This means that company leverage have an indirect and negative effect on company liquidity. Contrast to previous research, study [1] states that higher leverage will increases company liquidity. The results of this study are consistent with a view that debt will force managers to make better investment decisions [2]. It is because the manager with insolvency investment decisions can lead managers lose control and favorable reputation [24]. Based on that fact [25] showed that higher profitability caused by LBOs related to agency costs reduction. Lower agency costs between managers and stockholders and also lower information asymmetry will increase stock liquidity [26].

Openness and transparency (full disclosure) are a condition to make a fair market, so that Islam prohibits trade with Tadlis (manipulation and fraud) in any form. Islam prohibits transactions the informed trader with uninformed traders that damaging the uninformed trader. Islam requires transaction with full disclosure. Ideally information asymmetry phenomena will not occur if both parties apply Islam trade principles. Although there are differences research results the debt effects on company stock liquidity (positive and negative), but early indications show that in Indonesian stock market, for 45 most liquid stocks traded (LQ45), most of them (60\%) were categorized as stock sharia. Therefore, the first study hypothesis is:

H1: Sharia stocks liquidity will be better than non sharia stock liquidity in manufacturing industry.

Institutional transactions allow more information control [27,28,29,30], and large institutional ownership increases asymmetry information $[6,16,23,31]$. So the institutional ownership has a negative effect on stock liquidity. Therefore, second study hypothesis is:

H2: Institutional ownership will reduce liquidity of sharia and non sharia stocks.

One factor that caused stock illiquidity is informed traders presence. One group of informed traders is company internal party. Trades by insiders create abnormal changes in company stock price [32]. Therefore, insider ownership level in a company can affect stock liquidity. The greater insider ownership, the greater insider trading probability and also the larger bid-ask spreads and information asymmetry. It makes company stock liquidity will decrease [5]. Therefore, the third study hypothesis is:

H3: insider ownership will decrease the liquidity of sharia and non sharia stocks.

The blockholders ownership presences are expected can oversee the operation [33], reduce agency costs and increase company value [34,35,36]. However, blockholders ownership has potential costs, because they can provide oversight to private blockholders to access the valuable relevant company information. Market participants eliminate losses from informed traders to charge a wide spread and reduce the number of stocks offering to respond the higher probability of informed trading. In addition, study results of [6.10] also stated that institutional blockholding negative effect on stock liquidity. Therefore, based on theory and research that has been done the fourth study hypothesis is:

H4: blockholder ownership will reduce sharia and non sharia stocks liquidity

Participation by major international financial institutions will increase local markets liquidity through better disclosure and more actively trading. It makes information asymmetry level in stock trading lower [37]. This is supported by studies results of $[11,12]$ which suggests that market liquidity increases after stock market liberalization in emerging economies. However, these results contradict with study a result of [13] which states that stocks ownership by foreign institutional lower the stock liquidity. It is because ownership by large institutions will improve information asymmetry level $[6,16,23,31]$. Therefore, based on theory and research that has been done, the fifth study hypothesis is follows;

H5: $\quad$ Foreign institutional ownership will reduce sharia and non sharia stocks liquidity

Active stocks with high transaction volume make informed traders presence lower than liquidity traders. This statement is reinforced by study results of [20] which states, Easley et al., (1996), "...that the risk information-based trading is lower for active stock than it is for infrequently traded securities". Therefore, the high-volume stocks have lower spread than low volume stocks. It can be said the higher volume transactions, the higher stock liquidity $[1,5,15,20]$. Therefore, based on theory and research that has been done the sixth study hypothesis are follows;

H6: $\quad$ Greater trade volume will increase sharia and non sharia stocks liquidity.

Stock price is one factor considered by investors to invest in stocks. Price also has high effect on investor ability to buy stock. It is affect on stock liquidity. Adversely, very low stock price may makes these stocks is also not attractive and potentially not traded actively and therefore contributes to stock liquidity. Study results of [8] indicate that stock price has a negative effect on stock liquidity in Australian Stock Exchange. 
However, some previous studies result state that stock price has a positive effect on company stock liquidity, the higher stock price then the more liquid of company stock [5, 6,10,16,17]. Therefore, based on theory and research that has been done before the seventh study hypothesis is follows;

H7: $\quad$ Higher stock price will increase sharia and non sharia stock liquidity

In addition to show the risk levels, return volatility can also indirectly measure information asymmetry level among market participants [39]. The higher return volatility, the higher information asymmetry level (adverse selection) among market participants. The higher information asymmetry, the greater the bid-ask spread. It can be concluded that return volatility has a negative effect on stocks liquidity $[1,5,6,8,10,15]$. Therefore, based on theory and research that has been done the eighth study hypothesis are follows;

H8: $\quad$ Higher return volatility will reduce sharia and non sharia stocks liquidity

Market to book value negatively related to illiquidity [6.18]. . High market to book ratio indicates high stocks growth, and market to book low indicates low stocks growth. Higher market to book will increase company growth opportunities and will also increase company liquidity. Therefore, based on theory and research that has been done the ninth study hypothesis are follows;

H9: $\quad$ Higher market to book value will increase sharia and non sharia stocks liquidity.

Corporate dividend policy also affects company equity trading behavior because investors do not have to sell the stocks to realize profits from companies that have paid dividends. Dividend policy is also associated with the client company [40], and therefore related to company stock liquidity [16]. Based on the theory and research that has been done the tenth study hypothesis are follows;

H10: $\quad$ Companies dividend will increase sharia and non sharia stocks liquidity

The larger company, the greater company stock market value. This means company can achieve its goals and providing prosperity for stockholders. This condition causes many investors want company stock. The more investors who want the stock, the easier to sell (buy) the stock and consequently inventory-holding cost component in bid-ask spread decreases. The results $[1,6,15,41]$ have also indicated company size has positive effect on stock liquidity. Therefore, based on theory and research that has been done the eleven study hypothesis are follows;

H11: Larger companies size will increase sharia and non sharia stocks liquidity.

\section{Research Methods}

This study uses quantitative or positivist approach. The research was conducted in the manufacturing industry listed on Indonesia Stock Exchange (IDX) and the stocks are classified as sharia and non sharia stocks according to the National Sharia Council and Bapepam-LK. The time period of this study is 2009-2010.

Study population was divided into 2 (two) sub-populations, manufacturing companies whose stocks are classified as syariah stocks and manufacturing companies whose stocks are classified as non sharia stock. Sub populations manufacturing companies whose stocks are classified as syariah stocks have following criteria: (1) from 2009 to 2010 was classified as sharia stocks based decision agency chairman of capital markets supervisory and financial institutions of Kep-121/BL/2009, Kep- 416/BL/2009, Kep-208 / BL/2010 and KEP523/BL/2010 about sharia securities list during the period. (2) Having trade data of 2009-2010 relating to ask price, bid price, ask and bid volume daily available in Indonesia Stock Exchange. (3) Publishing financial reports from 2009 to 2010. Sub populations non sharia manufacturing companies are the company that not included in sharia stocks based agency chairman of capital markets supervisory and financial institutions decision of Kep-121/BL/2009, Kep-416/BL/2009 , Kep-208 / BL/2010 and KEP-523/BL/2010 about sharia stock list during 2009 to 2010 period. Two following criteria same with the sub-populations of manufacturing companies whose stocks are classified as syaria stock. Based on of sub-populations criteria above, subpopulations sharia stock of manufacturing companies that listed in Indonesia Stock Exchange are 46 companies, sub-populations non sharia stock are 32 companies.

Stock liquidity of sharia and non sharia stock in this study was measured by relative spread and depth.

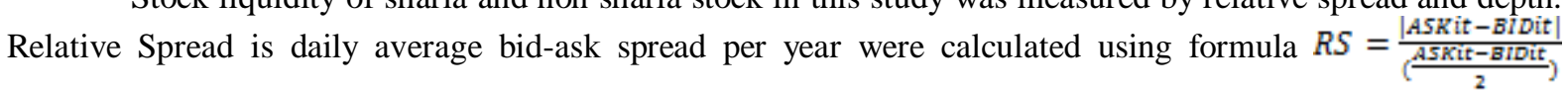
where $A S K_{i t}$ and $B I D_{i t}$ respectively are best ask and bid prices every day. The second measurement is depth measured using the natural logarithm (ln) of daily average depth per year, where daily depth is obtained from $D_{\text {it }}=A S K_{\text {it }} \times Q_{i t}^{A}+B i d_{i t} \times Q_{\text {it }}^{B}$, where $Q_{\text {it }}^{A}$ and $Q_{\text {it }}^{B}$ are volume of stocks available to trade at best quotes.

Liquidity determinants of sharia and non sharia stock used in this study are institutional ownership (INST), insider ownership (INSD), blockholder ownership (BLOCK), foreign institutional ownership (FINST), 
trading volume (VOLM), stock price (PRICE), return volatility (VOLT), Market to book value (MARKTB), dividend policy (DEV) and company size (SIZE). Institutional ownership (INST) is stock ownership proportion that owned by institutional stockholders, measured by comparing the number of common stocks owned by institutional stockholders at end of year with outstanding stock at end of year. Insider ownership (INSD) a company stockholder from within company (management and commissioners) was measured by comparing common stocks held by management and commissioners. Blockholder ownership (BLOCK) is concentration level ( $\geq 25 \%$ ) of company stock ownership measured by comparing the blockholder ownership $(\geq 25 \%)$ by stocks outstanding. In Indonesia regulations on companies control is regulated in capital Markets Act, 1995, the Chairman of Bapepam Kep.05/PM/2002 and Directors Decision of Jakarta Stock Exchange. Kep-305/BEJ/072004. Controller of a public company is a party that has stake $25 \%$ or more who have ability, either directly or indirectly, to control company. Foreign institutional ownership (FINST) is stock ownership level by foreign institutional stockholders or legal entity stockholder. Foreign institutional ownership is measured by comparing common stocks owned by foreign institutional stockholders at end of year with outstanding stocks at end of year.

Trading volume (VOLM) is average trading volume of daily stocks traded by trader every year. Stock price (PRICE) is the average stock market closing price per day in one year. Return volatility (VOLT) is variability of stock returns over time. Return volatility measured by standard deviation of daily stock returns every year. Market to Book value (MARKTB) is measured by dividing market value of equity and book value of company at end of year. Dividend policy (DEV) is company's decision to pay or not pay dividends to stockholders. This variable using is measured by dummy variables. If company pays dividend the dummy value is 1 and 0 for otherwise. Company size is how big a company based on market capitalization. Company size (SIZE) is measured using the natural logarithm (ln) of company market value at end of year.

Principally, independent sample t test examines stock liquidity differences, including relative spread and depth between sharia and non sharia stock. The aim is to prove hypothesis that sharia stocks liquidity is better than non sharia at manufacturing companies listed on Indonesia Stock Exchange (IDX).

Model I :

Multiple regression model used in this study are follows:

$$
\begin{gathered}
\operatorname{SPREAD}_{i, t}=\alpha+\beta_{1} \operatorname{INST}_{i, t}+\beta_{2} \operatorname{INSD}_{i, t}+\beta_{3} \text { BLOCK }_{i, t}+\beta_{4} \text { FINST }_{i, t}+\beta_{5} \operatorname{VOLM}_{i, t}+\beta_{6} \text { PRICE }_{i, t}+\beta_{7} \\
\operatorname{VOLT~}_{i, t}+\beta_{8} \operatorname{MARKTB}_{i, t}+\beta_{9} D E V_{i, t}+\beta_{10} \operatorname{SIZE}_{I, t}+\varepsilon_{i, t}
\end{gathered}
$$

Model II :

$$
\begin{gathered}
D E P T H_{i, t}=\alpha+\beta_{1} \operatorname{INST}_{i, t}+\beta_{2} \operatorname{INSD}_{i, t}+\beta_{3} \text { BLOCK }_{i, t}+\beta_{4} \text { FINST }_{i, t}+\beta_{5} \operatorname{VOLM}_{i, t}+\beta_{6} P_{\text {RICE }}+\beta_{i, t} \\
\operatorname{VOLT}_{i, t}+\beta_{8} \operatorname{MARKTB}_{i, t}+\beta_{9} D E V_{i, t}+\beta_{10} \operatorname{SIZE}_{l, t}+\varepsilon_{i, t}
\end{gathered}
$$

Both model I and model II are analyzed in sharia and non sharia stocks at manufacturing industries listed in Indonesia Stock Exchange.

Multiple regression analysis is used test the effect of each independent variable of institutional ownership, insider ownership, blockholder ownership, foreign institutional ownership, trading volume, stock price, return volatility, market to book value, dividend policy, company size toward dependent variable (stock liquidity) and how strong the effect of each independent variable toward dependent variable.

In addition, to support results description of quantitative research findings in this study, it conducted in deep interview with capital market actor, such as; investment managers, stock brokers and other actor in Indonesia Stock Exchanges who understand sharia stocks concept. It is also intended to confirm the findings quantitatively with market participants in order to get a deep understanding of sharia and non sharia stock liquidity and their determinant.

\subsection{Hypothesis Testing}

\section{Results and Data Analysis}

Tables. 2 shows the $t$ test results of sharia and non stocks related to their spread and depth.

Table 2: Difference test results of sharia and non stocks related to their spread and depth

\begin{tabular}{|l|c|c|}
\hline \multicolumn{1}{|c|}{ Stock type } & Spread Average & Depth (Ln) Average \\
\hline Syaria & 0.0711 & 18.1474 \\
Non Syaria & 0.0664 & 18.3936 \\
\hline T test (p-value) & 0.691 & 0.449 \\
\hline Description & Insignificant & Insignificant \\
\hline
\end{tabular}

Based on difference test results of sharia and non stocks related to their spread, it can be seen that pvalue is 0.691 . Because p-value $(0.691)>0.05$, it can be concluded that spread difference between sharia and 
non sharia stocks in manufacturing companies is not significant. In addition, based on difference test results of sharia and non stocks related to their depth, it can be seen that p-value $(0.449)>0.05$, it can be concluded that depth difference between sharia and non sharia stock in manufacturing companies is not significant. Generally, based on difference test results of sharia and non stocks related to their spread and depth, it can be stated that research hypothesis stating sharia stock liquidity is better than non sharia stocks liquidity is rejected.

Table 3 shows results of OLS regression testing variables the determinants of liquidity (spread and depth) of sharia and non sharia stocks. They are institutional ownership (INST), insider ownership (INSD), blockholder ownership (BLOCK), foreign institutional ownership (FINST), trading volume (VOLM), stock price (PRICE), return volatility (VOLT), Market to book value (MARKTB), dividend policy (DEV) and company size (SIZE).

Table 3: OLS regression result the determinants of liquidity (spread and depth) of sharia and non sharia stock.

\begin{tabular}{|c|c|c|c|c|}
\hline \multirow{2}{*}{$\begin{array}{c}\text { Independent } \\
\text { Variables }\end{array}$} & \multicolumn{2}{|c|}{ Sharia Stock } & \multicolumn{2}{|c|}{ Non Syaria Stock } \\
\hline & Spread & Depth & Spread & Depth \\
\hline Constant & $\begin{array}{l}.411 * * * \\
(0.000) \\
\end{array}$ & $\begin{array}{c}2.129 \\
(0.184) \\
\end{array}$ & $\begin{array}{l}.504 * * * \\
(0.000) \\
\end{array}$ & $\begin{array}{l}4.376 \\
(0.66) \\
\end{array}$ \\
\hline INST & $\begin{array}{c}0.038 \\
(0.337) \\
\end{array}$ & $\begin{array}{c}-2.351 * * * \\
(0.001)\end{array}$ & $\begin{array}{l}-0.050 \\
(0.225) \\
\end{array}$ & $\begin{array}{l}-0.813 \\
(0.420) \\
\end{array}$ \\
\hline$I N S D$ & $\begin{array}{l}-0.008 \\
(0.881) \\
\end{array}$ & $\begin{array}{l}-1.434 \\
(0.106) \\
\end{array}$ & $\begin{array}{l}-0.241 \\
(0.198) \\
\end{array}$ & $\begin{array}{c}2.339 \\
(0.610)\end{array}$ \\
\hline$B L O C K$ & $\begin{array}{l}-0.021 \\
(0.380)\end{array}$ & $\begin{array}{c}0.399 \\
(0.316) \\
\end{array}$ & $\begin{array}{c}0.007 \\
(0.821)\end{array}$ & $\begin{array}{c}0.726 \\
(0.321) \\
\end{array}$ \\
\hline FINST & $\begin{array}{c}0.007 \\
(0.701) \\
\end{array}$ & $\begin{array}{c}1.068 * * * \\
(0.001)\end{array}$ & $\begin{array}{c}0.026 \\
(0.155)\end{array}$ & $\begin{array}{c}0.108 \\
(0.806) \\
\end{array}$ \\
\hline VOLM & $\begin{array}{c}-.020 * * * \\
(0.000)\end{array}$ & $\begin{array}{l}.405^{* * *} \\
(0.000)\end{array}$ & $\begin{array}{c}-.018 * * * \\
(0.000)\end{array}$ & $\begin{array}{l}.358 * * * \\
(0.000)\end{array}$ \\
\hline PRICE & $\begin{array}{c}-5.872 \mathrm{E}-07 \\
(0.279)\end{array}$ & $\begin{array}{c}1.073 \mathrm{E}-005 \\
(0.231)\end{array}$ & $\begin{array}{c}-6.319 \mathrm{E}- \\
007 * * * \\
(0.002)\end{array}$ & $\begin{array}{c}1.263 \mathrm{E}-005^{* *} \\
(0.012)\end{array}$ \\
\hline VOLT & $\begin{array}{c}0.103 \\
(0.792)\end{array}$ & $\begin{array}{l}-9.026 \\
(0.165)\end{array}$ & $\begin{array}{c}0.085 \\
(0.814)\end{array}$ & $\begin{array}{c}-13.668 \\
(0.128)\end{array}$ \\
\hline$M A R K T B$ & $\begin{array}{c}0.000 \\
(0.862) \\
\end{array}$ & $\begin{array}{l}-0.020 \\
(0.442) \\
\end{array}$ & $\begin{array}{c}0.000 \\
(0.600) \\
\end{array}$ & $\begin{array}{c}0.016 \\
(0.130) \\
\end{array}$ \\
\hline $\mathrm{DEV}$ & $\begin{array}{l}-.034 * * \\
(0.012) \\
\end{array}$ & $\begin{array}{c}.407 * \\
(0.062) \\
\end{array}$ & $\begin{array}{l}-0.001 \\
(0.946) \\
\end{array}$ & $\begin{array}{c}0.505 \\
(0.130) \\
\end{array}$ \\
\hline Size & $\begin{array}{l}-0.003 \\
(0.406)\end{array}$ & $\begin{array}{l}.447 * * * \\
(0.000)\end{array}$ & $\begin{array}{l}-.007 * \\
(0.058)\end{array}$ & $\begin{array}{l}.364 * * * \\
(0.000)\end{array}$ \\
\hline $\mathrm{R}^{2}$ & 0.640 & 0.859 & 0.736 & 0.802 \\
\hline
\end{tabular}

Description:

***, Significant at $1 \%$

**, Significant at $5 \%$

*, Significant at $10 \%$

Table 3 shows that volume of trade (VOLM) and dividend policy (DEV) has a significant negative effect on relative spread of sharia stocks. This shows the higher trading volume, the lower relative spread. It means sharia stocks liquidity become higher. In addition, the dividend policy decrease significantly relative spread of sharia stocks. It also means increasing sharia stocks liquidity. Institutional ownership (INST), insider ownership (INSD), blockholder ownership (BLOCK), foreign institutional ownership (FINST), stock price (PRICE), return volatility (VOLT), Market to book value (MARKTB) and company size (SIZE) have no significant effect on relative spread of sharia stocks. In non sharia stocks, trading volume (VOLM), stock price (PRICE) and company size (SIZE) has a significant negative effect on relative spread. This shows that increasing trading volume (VOLM), stock price (PRICE) and company size (SIZE), the lower relative spread also means the higher stock liquidity. However, institutional ownership (INST), insider ownership (INSD), blockholder ownership (BLOCK), foreign institutional ownership (FINST), return volatility (VOLT), Market to 
book value (MARKTB) and dividend policy (DEV) has no significant effect on relative spread of non sharia stocks.

Institutional ownership (INST) has a significant negative effect on depth of sharia stocks. This suggests that institutional ownership (INST) decrease depth of sharia stocks. Foreign institutional ownership (FINST), trading volume (VOLM), dividend policy (DEV) has a significant positive effect on depth of sharia stocks. It also shows the higher foreign institutional ownership (FINST), trading volume (VOLM), dividend policy (DEV), the greater depth of sharia stocks. Furthermore, trading volume (VOLM), price (PRICE) and company size (SIZE) has a significant positive effect on depth non sharia stocks. This shows the higher trading volume (VOLM), price (PRICE) and company size (SIZE), the higher depth of non sharia stock. However, institutional ownership (INST), insider ownership (INSD), blockholder ownership (BLOCK), foreign institutional ownership (FINST), return volatility (VOLT), Market to book value (MARKTB) and dividend policy (DEV) has no significant effect on depth of non sharia stocks.

\subsection{Information from Key Informants}

Discussions were conducted with key informants, include; academics who understand sharia stocks, investment managers who understand sharia stocks, staff Indonesia Stock Exchange, investors and investment consultants, in order to confirm the research results qualitatively. Research shows empirical phenomena findings related to sharia and non sharia stock, namely:

- Most investors who invest in sharia stocks are investors with relatively long-term investment, while investors who invest in non sharia stocks orient to short term. Therefore, most sharia stocks investors use fundamental and technical approach in analyzing stocks, while sharia stocks investors largely use technical approach. Technical approach gives investors opportunity to speculate in stock market in short term.

- Most actor of capital market in Indonesia is speculator who does not distinguish whether the stocks are traded in accordance with sharia or not. They are based on profit motive or mere rationality in investment regardless whether they are invest in accordance with sharia principle (spirituality) or not.

- Brokerage companies role are very large to create speculators on stock exchange. This relates to fees they earn from transactions conducted by its customers. The more often customers buy and sell stock market, the greater fee they received, and brokers are also targeted the amount of transactions made customers by stock company. Thus, the broker always encourage customers to transact in the market using information that not obvious truth and often based on daily rumors in market (speculative transactions).

- Foreign investors have are very large role to influence domestic investors behavior in capital market. Most speculators in market are those who follow stock transactions made by foreign investors (follower). More than $50 \%$ of outstanding stocks in Indonesia are owned by foreign investors. Foreign investors have very dominant role in moving capital markets in Indonesia and most of foreign investors are from non-Muslim countries that do not distinguish sharia stocks from non sharia stock.

- Sharia capital market in Indonesia is only based on product approach (stocks) traded. However, the transaction being done on stock exchanges are still applying conventional practices that not accordance with sharia as short sells and margin trading. Therefore, actually there are people who think that there is no sharia capital market in Indonesia and sharia stocks presence does not affect on investor behavior because investors still use sharia and non sharia stock one means to speculate.

- From company's point of view, the inclusion their stocks into Sharia stock category do not give prestige or pride. Company does not care weather their stock included in sharia or non sharia classification.

- Indonesia Stock Exchange development is very high after his fall at the end 2008. It makes investors come back quickly into market (panic buying) to take advantage without considering whether they buy sharia or non sharia stock.

\subsection{Sharia and Non Sharia Stock Liquidity}

\section{Discussion and Conclusion}

Independent $t$ test results on relative spread and depth for sharia and non sharia stocks shows no difference the relative spread and depth in both stocks types. This means that sharia stocks classification under direction of National Sharia Board and Bapepam - LK No. IX.A.13 about Sharia Stock Issuance are not able to make the sharia stock liquidity better than non sharia stock liquidity in manufacturing companies listed on Indonesia Stock Exchange from 2009-2010. Although at one point classification criteria of sharia stocks have clear limit, the company capital structure classified as syariah has $45 \%$ from debt and 55\% from own capital, but it still not able to increase the sharia stocks liquidity .

This study result are not directly inconsistent with a view that investors have lower interest to trade and hold companies stocks with high debt. It make bid and ask spread of these stocks became wider [1.23]. In addition, this study results are also inconsistent with a view that debt forces managers to make better investment 
decisions [2]. This is because when manager wrong in investment decisions, the bankruptcy can lead managers will lose control and favorable reputation.

Inability of sharia stocks classification makes stock liquidity better than non sharia stocks. This is due to several things such as; large number of speculators who trade in Indonesia Stock Exchange, investors less knowledge about sharia stocks, stock trading system does not support the application of sharia stock transactions process, and companies outlook that sharia stocks classification is not something prestigious for issuers (companies)

Most investors in Indonesia Stock Exchange are speculators who bought and sold stocks in short term and using short term rumor with questionable truth. They are seldom use fundamental approach. This is similar to Leo Herlambang opinion that most of capital market actors in Indonesia Stock Exchange are speculator. Speculators seldom use fundamental analysis. In addition, fundamental approach requires considerable time in analyzing stock prices and speculator in Indonesia Capital Market less able in mastering fundamental approach to analyze stocks.

Speculators in Indonesia generally use technical analysis approach, an approach that using unclear rumors and becoming follower of foreign investors in making decision to buy or sell stocks, without considering sharia stocks characteristics as a differentiating factor with non sharia stocks. In addition, according to Leo Herlambang, Isma Swadjaja and Bambang, brokerage companies role have very large effect in creating speculators. This relates to stock transaction fees they received. The more often investors make transactions, the greater fee received. Therefore, brokers encourage investors to trade frequently in stock markets, although providing information based on unclear rumors. This condition makes Indonesia Stock Exchange has high stock price index fluctuations.

Investor low knowledge about sharia stocks also one factor make sharia stock liquidity not higher than non sharia stocks in manufacturing companies. It is caused by less socialization of sharia instruments in capital markets, as well as the low level of Islamic and sharia stock implementation to investors in buying and selling stocks. In addition, according to Leo Herlambang, a practitioner (investment manager) and academics of capital markets, high transaction conducted by domestic and foreign investors who expect profits solely without considering spirituality in Indonesia Stock Exchange today, certainly not consider whether their stocks traded in accordance with sharia or not. This all does not affect the higher sharia stock liquidity than non sharia stock.

Sharia capital market developments in Indonesia today only at product approach level, that is sharia stocks. However, stock system trading did not support the application of sharia stock transaction. Until now there is no provision to legitimate sharia capital market from Bapepam or government, for example, Rule and Law about sharia capital markets. Sharia stock trading system in Indonesia Stock Exchange still follow conventional trading system that allows margin trading transactions and speculation. It leads to gambling and contrary with Islamic sharia. In other words, stock market during this practice can not be separated from usury, gharar and maysir. This is similar to what was raised by Bambang, an investor and stock investments consultant, which states that in transaction process there is no difference between sharia stocks and non sharia stock. Market participants are still able to make margin trading and short selling in Indonesia capital market which is clearly contrary to Islamic sharia. Although they trade sharia stocks but the trade violates Islam sharia and it is haram (forbidden). At the end, it does not make goodness to sharia stock liquidity itself.

In addition, sharia stocks classification do not include an assessment of how operations carried out by management everyday, how openness and transparency principles is adopted by company, whether it is suitable with sharia or not. The companies information asymmetry level of syariah stocks should lower than non sharia stock. Because openness and transparency (full disclosure) is a condition to make fair market, Islam prohibits trade containing Tadlis (manipulation and fraud) committed by parties who receive unfair information from company, in any form [4].

Sharia stocks classification is not something prestigious for issuers (companies). Issuer considers the announcement whether the stocks are listed as sharia stock or not by Bapepam and LK is considered as something usual. Listed and unlisted of company stock in sharia stock do not affect the rise and fall of stock prices. According to Leo Herlambang, many companies with non sharia stock have debt to capital stock ratio higher than sharia criteria, having better company value than company classified as syariah stock. It is because many investors believe that company with high debt has many investment opportunities that benefit to companies and projected they have substantial growth in future. In other words, the debt will increase company value in future. Therefore, sharia stocks classification do not give goodness to company operations and company stock liquidity .

\subsection{Determinants of Sharia and Non Sharia Stocks Liquidity}

Capital market actor (Market makers) in Indonesia does not consider the ownership structure, in this research are institutional ownership (INST), insider ownership (INSD), blockholder ownership (BLOCK), foreign institutional ownership (FINST), as party that controlling private company information. It makes 
adverse selection costs on components spread of sharia and non sharia stocks. The results of this study do not support notion that institutional transactions are more likely to control information ([27,28,29,30] and large institutional ownership increases information asymmetry [6,16,23,31]. In addition, this results study does not support study results of [5] which states insider ownership is positively related to bid-ask spreads and information asymmetry. Greater insider ownership does not make greater probability of insider trading that making bid-ask spreads become bigger. Related to blockholder ownership, this study results contrary with study results of $[6,10]$ which found that blockholder ownership negatively affect stock liquidity. Huge foreign institutional ownership in sharia and non sharia stocks do not increase asymmetry information in stock market. It does not increase relative spread for both stocks types. These study results are inconsistent with [13] which states that foreign institutional stockholdings increased bid-ask spread.

Ownership structures insignificance, including institutional ownership (INST), insider ownership (INSD), blockholder ownership (BLOCK), foreign institutional ownership (FINST) on relative spread of sharia and non sharia stocks in this study was caused by:

1. Indonesia Stock Exchange improvement in this study period. Financial crisis 2008 in United States had a strong effect on capital market in Indonesia, especially Indonesia Stock Exchange. In October 2008, stock price index comes to worst performance. Composite Stock Price Index decreased by 50.64\% the level 2745.826 at end of 2007 and was closed at 1355.408 levels at end of 2008. After 2008, stock Exchange trading activity in Indonesia increased rapidly. Fast recovery of Indonesian Stock Exchange due to increased investor confidence in Indonesia's economic fundamentals that pretty good and the fall of Indonesia Stock Exchange in 2008 only caused by psychological factors of excessive panic over the fall of world stock exchanges, especially the New York Stock Exchange (NYSX). The recovery in investor confidence, both domestic and foreign, making Composite Stock Price Index (CSPI) increases significant in 2008-2010 period, average of $66.57 \%$ per year, the market capitalization value also increase significantly, on average $74.19 \%$ per year. In addition, trade volume in 2008-2009 increased $86.29 \%$ and trading frequency increase $56.35 \%$. This shows a very high trading activity and market liquidity (low spreads) as well. In investment decisions making, investors do not consider ownership structures as a component of adverse selection leading to high cost (information asymmetry), as a spread component of sharia and non sharia stocks in manufacturing companies.

2. Many investors make speculation in Indonesia Stock Exchange. Most investors in exchange transactions are speculative in buying and selling stocks in stock market and it is short term in nature, both for sharia and non sharia investor. These investors tend to make decisions without clear fundamental information and based on rumors. According to Isma Swandono "most people have speculated with short-term time or temporary and motivated by brokers behavior that encourage investors to invest in short term because the more often investors trade the bigger fees received". So in this case brokers play important role to create speculators in Indonesian capital market. In addition, most of these investors use technical analysis approach in making decisions to sell or buying stocks.

The results also show the higher institutional ownership on stocks sharia, the lower trading activity (frequency). It makes market has lower ability to transfer stocks large quantity without causing a decline in stock prices (depth). In addition the entry of foreign investors to manufacturing companies with syariah stocks classification in Indonesia Stock Exchange create high market capability to transfer large quantity stocks without causing stock price fall (depth), particularly manufacturing company with sharia stocks classification. However, this phenomenon does not occur in manufacturing companies with non sharia stocks classification.

High transactions volume on sharia and non sharia stock of manufacturing companies show large sell (buy). This means turnover is quick and having high liquidity. In addition, the high volume of stock transactions show low opportunity cost to hold the stock. Therefore, stocks transactions volume determines sharia and non sharia stocks liquidity.

Most of non sharia stock investors has low level in understanding and practicing Islam sharia and has a tendency to make short-term investment and very attentive to movements and stock price trend as a variable used in technical analysis to assess stock. Therefore, stock price is a determining factor of non sharia stocks liquidity of manufacturing company. Differ with non sharia stocks, most sharia stocks investors hold stocks in relatively longer period than non sharia stock investors because bankruptcy risk the companies whose stocks classified as syariah stocks is lower. Therefore, daily stock price movements do not determine sharia stock liquidity.

Return volatility is quite high during study period. When a Stock Exchange condition is bullish, it does not reflect that informed trader cause information asymmetry phenomenon. These conditions make market participants do not consider the return volatility as stock liquidity determinants (spread and depth), either in sharia or non sharia stock of manufacturing industry go public in Indonesia Stock Exchange.

Investor psychological conditions with euphoria capital markets rose sharply after the fall in 2008 and pivotal role of speculators in Indonesia Stock Exchange makes fundamental analysis with market to book value 
indicators does not considered in investment. Therefore, market to book value does not determine liquidity (spread and depth), both for sharia and non sharia stock in manufacturing industry.

Dividend stock is a component expected by investors, in this case the investor who invests in a relatively long-term, such as sharia stocks investors. Long-term investors will always look at risks of company's bankruptcy related to debt burden. Company with sharia stocks on average have a lower bankruptcy risk than companies with non sharia stocks. Long-term oriented investors will choose to invest in stocks sharia. Therefore, dividend policy is a factor that determining sharia stocks liquidity in manufacturing companies. Adversely, non sharia stock investors have characteristic to invest in relatively short-term, more speculative and expecting capital gains, not dividends distributed by company. It makes the effect of dividend policy on non sharia stock liquidity is not significant at manufacturing industry.

Large companies stock more frequent and easier to trade than small companies stocks in Indonesia Stock Exchange. Therefore, company size affects market ability to absorb large amounts of transactions without causing stock price collapse (depth), both for sharia and non sharia stock of manufacturing company. Moreover, large companies given greater attention from investors, especially companies with non sharia stocks classification have an average proportion of debt to assets relatively large. It makes information asymmetry level and spread will smaller than small companies. However, company size is not a determining factor for sharia stocks spread. It is because most investors who invest in sharia stocks are long-term investors who concerning bankruptcy risk factors and did not consider company size as determinants of sharia stocks spread.

Table 4 below shows the comparison between sharia and non sharia stocks summarized from this study results, both from quantitative result and from discussions with key informants, namely investment managers, brokers, stock exchanges staf. In addition, literature studies also completing the comparison between sharia and non sharia stocks.

Table 4: Comparison of sharia and non sharia stocks

\begin{tabular}{|c|c|c|}
\hline Description & Sharia stock & Non sharia stock \\
\hline Company bankrupty risk & $\begin{array}{l}\text { Lower because company had average debt-to- } \\
\text { asset ratio up to } 45 \%\end{array}$ & $\begin{array}{l}\text { Higher because company had average } \\
\text { debt-to-asset ratio higher than } 45 \%\end{array}$ \\
\hline Company product & Not allowed to produce haram goods & Allowed to produce haram goods \\
\hline Investment period & $\begin{array}{l}\text { Long-term, it is because bankruptcy risk is } \\
\text { small }\end{array}$ & $\begin{array}{l}\text { Short-term, it is because bankruptcy risk } \\
\text { is bigger }\end{array}$ \\
\hline Investor category & Most of them Investor & Most of them Spekulator \\
\hline Investor motive & $\begin{array}{l}\text { Most of them profit oriented. Only a minority } \\
\text { investor oriented to partial implementation of } \\
\text { Islamic sharia in life (spiritual oriented). }\end{array}$ & Only profit oriented \\
\hline Investor Approach & $\begin{array}{l}\text { Most of them use fundamental and technical } \\
\text { approach, taking into account stock liquidity } \\
\text { determinants such as institutional ownership, } \\
\text { foreign institutional ownership, trading } \\
\text { volume, dividend policy and size (market } \\
\text { capitalization). }\end{array}$ & $\begin{array}{l}\text { Most of them tend to use technical } \\
\text { rather than fundamental approach, } \\
\text { taking into account stock liquidity } \\
\text { determinant such as trading volume, } \\
\text { stock price, size (market capitalization). }\end{array}$ \\
\hline $\begin{array}{l}\text { Stock transaction process in } \\
\text { Stock Market }\end{array}$ & $\begin{array}{l}\text { Not different from with non sharia stocks. } \\
\text { Margin trading and short sell transactions that } \\
\text { not suitable to sharia is still allowed, so } \\
\text { forbidden action still mixed with lawful action. } \\
\text { Therefore, sharia capital market existence only } \\
\text { product approach and still contain gambling } \\
\text { elements and high speculation }\end{array}$ & $\begin{array}{l}\text { Not differ with sharia stocks. Margin } \\
\text { trading and short sell transactions are } \\
\text { allowed. Investors also assume there is } \\
\text { no difference between sharia and non } \\
\text { sharia capital market because they have } \\
\text { same place and trade system }\end{array}$ \\
\hline
\end{tabular}

\subsection{Limitations and future studies}

The research was done when time and market conditions are bullish (2009-2010), so this study results can not be generalized to bearish market conditions. Therefore, future studies are expected to be done in a relatively long time period to generalize differences of sharia and non sharia stock liquidity in manufacturing industries listed in Indonesia Stock Exchange.

This study did not include macroeconomic variables such as interest rates, exchange rates, inflation, national income and others as a determinant of sharia and non sharia stock liquidity. In emerging markets, macroeconomic development has a huge effect on capital market in the country, including Indonesian capital market. History has proven the fall of Jakarta Stock Exchange in 1998 caused by exchange rate crisis followed by very high interest rate increase at $67 \%$ per year. Therefore, further research could consider macroeconomic variables such as interest rates, exchange rates, inflation, and national income as a determinant factor of sharia and non sharia stock liquidity, in order to complete this research.

This research was conducted on sharia and non sharia stock of manufacturing companies. The results of this study can not be applied to sharia and non sharia stock in industries other than manufacturing companies. Therefore, future research should not restricted in manufacturing industry, thus generalization of study results will more extensive. 


\section{References}

[1] Frieder, L., and R. Martell., 2006. Capital Structure and The Liquidity of a Firm's Stock, Working paper, Purdue University.

[2] Jensen, M., 1986. Agency cost of free cash flow, corporate finance and takeovers. American Economic Review Papers and Proceedings, 76, pp. 323-329.

[3] O'Hara, M., 1995. Market Microstructure Theory, Cambridge MA: Blackwell

[4] Nafik, M., 2008. Bursa Efek dan Investasi Syari'ah: Kajian Pelanggaran Prinsip-Prinsip Syari'ah Pada Transaksi Bursa Efek Konvensional. Amanah Pustaka. Surabaya.

[5] Sarin, A, K. Shastri, and K Shastri. 2000. Ownership Structure and Stock Market Liquidity. Working Paper, University of Pittsburgh. USA.

[6] Rubin, A., 2007. Ownership Level, Ownership Concentration, and Liquidity. Journal of Financial Market, Vol.10, p: 219-248.

[7] Kothare, M., 1997, The effects of equity issues on ownership structure and stock liquidity: A comparison of rights and public offerings, Journal of Financial Economics 43, 131-148.

[8] Forde, C.C., and J. Rydge., 2005. Ownership Concentration, Insiders and Illiquidity. Finance Discipline, School of Business University of Sydney NSW 2006, April 2005, p:1-31.

[9] Brennan, M., and Subrahmanyam, 1996, Market microstructure and asset pricing: On the compensation for illiquidity on stock return, Journal of Economics 41, 441-464.

[10] Heflin, F and Shaw, K.W. 2000. Blockholder Ownership and Market Liquidity. Journal of Financial and Quantitative Analysis. Vol. 35, No.4: 621- 633.

[11] Bekaert, G., Harvey, C.R., Lundblad, C., 2002. Dating the integration of world equity markets. Journal of Financial Economics 65, 203-247.

[12] Levine, R., Zervos, S., 1998. Capital control liberalization and stock market development. World Development 26, 1169-1183.

[13] Rhee, S.G and Wang, J., 2009. Foreign International Ownership and Stock Market Liquidity: Evidence from Indonesia. Journal of Banking and Finance, Vol. 33, p: 1312-1324

[14] Easley, David, Nicholas M. Kiefer, Maureen O’Hara, and Joseph B. Paperman., 1996. Liquidity, Information and Infrequently Traded Stock. Journal of Finance. Vol. LI, No.4: 1405-1436.

[15] Corwin, SA, 1999. Differences in Trading Behavior across NYSE Specialist Firms, The journal of Finance, vol. liv, no. 2 , April 1999.

[16] Agarwal, P., 2009. Institutional Ownership, Liquidity and Liquidity Risk, doctoral dissertation, the Faculty of the Graduate School of Cornell University.

[17] Attig, N., W.M. Fong, Y. Gadhoum, and L.H.P. Lang., 2006. Effect of Large Shareholding on Information Asymmetry and Stock Liquidity. Journal of Banking and Finance. Vol 3, p: 2875-2892

[18] Blease, B., John R., Paul, and Donna L., 2006. Stock Liquidity and Investment Opportunities: Evidence from Index Additions.

[19] Elton, E.F., and M.J. Gruber., 1995. Modern Portofolio Theory and Investment Analysis. Fifth Edition. John Wiley \& Sons, Inc. : New York.

[20] Easley, David, Nicholas M. Kiefer, Maureen O’Hara, and Joseph B. Paperman., 1996. Liquidity, Information and Infrequently Traded Stock. Journal of Finance. Vol. LI, No.4: 1405-1436.

[21] Dunerv, A and E.H. Kim., 2003.To Steal of Not to Steal : Firm Attributes, Legal Environment, and Valuation. Working Paper

[22] Frieder, L., and A. Subrahmanyam., 2005, "Brand Perceptions and the Market for Common Stock", Journal of Financial and Quantitative Analysis 40, 65-85.

[23] Dennis, P.J., Weston, J., 2001. Who's informed? An analysis of stock ownership and informed trading. Working Paper.

[24] Grossman, S., and O. Hart, 1986, Corporate Financial Structure and Managerial Incentives (University of Chicago Press: Chicago).

[25] Bhagat, S., A. Shleifer, and R. Vishny, 1990, "Hostile Takeovers in the 1980s: The Return to Corporate Specialization", Brookings Papers on Economic Activity: Microeconomics, 1-72.

[26] Kyle, A., 1985, "Continuous Auctions and Insider Trading”, Econometrica 53, 1315-1336.

[27] Ali, A., Durtchi, C., Lev, B., Trombley, M., 2004. Changes in institutional ownership and subsequent earnings announcement abnormal returns. Journal of Accounting, Auditing, and Finance 19, 221-248.

[28] Pinnuck, M., 2004. What is the abnormal return performance of mutual funds due to earnings information? Working Paper, University of Melbourne

[29] Ke, B., Petroni, K., 2004. How informed are actively trading institutional investors? Evidence from their trading behavior before a break in a string of consecutive earning increases. Journal of Accounting Research 42, 895-927.

[30] Bushee, B.J., Goodman, T.H., 2007. Which institutional investors trade based on private information about earnings and returns. Journal of Accounting Research 45, 289-321

[31] Brockman, P., Yan, X., 2009. Block ownership and firm-specific information. Journal of Banking and Finance 33, $208-316$.

[32] Seyhun, H. N., 1986. Insiders' profits, costs of trading, and market efficiency. Journal of Financial Economics 16, $189-212$.

[33] Morck, R., A. Shleifer, and R, Vishny. 1988. Management Ownership and Market Valuation: An Empirical Analysis, Journal of Financial Economics, 20: 293-315

[34] McConnell, J. J., Sarvaes, H., 1990, Additional Evidence on Equity Ownership and Corporate Value, Journal of Financial Economics 25, 595-613.

[35] Barclay, M., Holderness, C., 1991, Negotiated block trades and corporate control, Journal of Finance 46, 861-878.

[36] Bethel, J., Liebeskind, J. P., Opler, T., 1998, Block share purchases and corporate performance, Journal of Finance 53, 650-653.

[37] Stulz, R., 1999. Globalization of equity markets and the cost of capital. In: NBER Working Paper, 7021.

[39] Anderson, T., 1996, Return volatility and trading volume: An information flow interpretation of stochastic volatility, Journal of Finance 51, 169-204.

[40] Grinstein, Y., and R. Michaely, 2005, Institutional holdings and payout policy, Journal of Finance , vol 60 (3), $1389-1426$.

[41] Elton, E.F., and M.J. Gruber., 1995. Modern Portofolio Theory and Investment Analysis. Fifth Edition. John Wiley \& Sons, Inc. : New York. 